\title{
Do Superior Thyroidal Artery Doppler Findings Play a Role in the Differential Diagnosis of Hyperthyroidism?
}

\section{Süperior Tiroidal Arter Doppler Bulgularının Hipertiroidizm Ayırıcı Tanısında Rolü Var mı?}

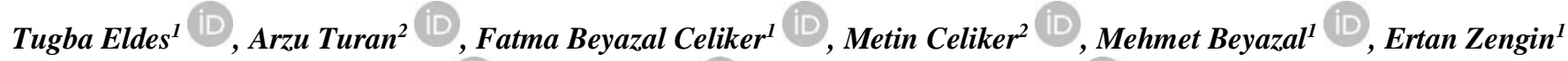 \\ Teslime Ayaz ${ }^{3}$, Mehmet Masum Simsek ${ }^{1}$
}

$\underline{\underline{Z Z}}$

Amaç: Hipertiroidinin erken tanı ve doğru tedavisi, ilişkili sistemik komplikasyonları önleyebilmek açısından önemlidir. Ayırıcı tanıda serum tiroid hormonları, tiroid otoantikorları ve radyoaktif iyot uptake sintigrafisi kullanılmakta ancak bu incelemelerle kesin tanıya gidilememektedir. Çalışmamızda laboratuar bulgularının yanında süperior tiroidal arterin dublex doppler ultrason bulgularının tanıya katkısını değerlendirdik. Bu doppler bulgularının, gri scala ultrasonografi bulgularına ek destekleyici bir yöntem olabileceğini göstermeyi amaçladık.

Araçlar ve Yöntem: Çalışmaya 75'i kadın ve 21'i erkek olmak üzere toplam 96 kişi dahil edildi. Hipertiroidili gruplar graves hastalığı (GD) ve toksik multınoduler guatrı olan (TMNG); sırasıyla 29 ve 41 kişiydi. Kontrol grubu olarak çalışmaya ötiroid 26 kişi dahil edildi. Tüm bireylere yapılan dublex doppler ultrason ile süperior tiroidal arterlerinin pik sistolik hız, end diastolik hız ve rezistivite index değerlerine bakıldı. Pik sistolik değerlerinin toksik multinodüler guatr grubunda graves hastalarına göre anlamlı yüksek olduğu bulundu.

Bulgular: TMNG and GD hastalarında, pik sistolik hız, diyastol sonu hız ve rezistif index değerleri kontrol grubuna göre anlamlı yüksek bulundu $(\mathrm{p}<0.001)$. TMNG ve GD hastaları karşılaştırıldığında ise sadece pik sistolik hız değeri TMNG’li grup lehine anlamlı yüksek bulundu. TMNG‘li grubun $(50.5 \pm 26.5 \mathrm{~cm} / \mathrm{sec})$ ve GD’li $(34.2 \pm 11.5 \mathrm{~cm} / \mathrm{sec})$ grubun pik sistoli hız değerleri klinik tanı anında karşılaştırıldı.

Sonuç: Hipertiroidi ayırıcı tanısında sintigrafinin gerekli olduğu yerlerde süperior tiroidal arterin pik sistolik hız de ğerlerinin kullanılabileceği kanaatindeyiz. Böylece alınabilecek potansiyel radyasyon dozu ve kaybedilecek zaman önlenebilir.

Anahtar Kelimeler: Hipertiroidizm; doppler ultrasonografi; pik sistolik hız

\section{ABSTRACT}

Purpose: Early diagnosis and treatment of hyperthyroidism are important to prevent associated systemic complications. Serum thyroid hormones, thyroid autoantibodies, and radioactive iodine uptake scintigraphy are used in diagnosis; but these investigations do not lead to a definitive diagnosis. In our study, we evaluated the contribution of the findings observed on duplex doppler ultrasonography of the superior thyroi dal artery to the diagnosis in addition to laboratory findings. Our aim was to show whether these findings could be alternatives to scintigraphy when scintigraphy is indicated.

Material and Methods: The study included 96 individuals consisting of 75 women and 21 men. Hyperthyroidism group included 29 and 41 patients with Graves' disease (GD) and toxic multinodular goiter (TMNG), respectively. 26 euthyroid individuals were also included in the study as a control group. Peak systolic velocity (PSV), end-diastolic velocity (EDV) and resistivity index (RI) values of superior thyroidal arteries were analyzed with duplex doppler ultrasonography.

Results: For PSV, EDV and RI values were significantly higher in patients with hyperthyroidism compared to the control group (p<0.001). PSV value was found statistically significantly higher in the TMNG group $(50.5 \pm 26.5 \mathrm{~cm} / \mathrm{sec})$ when compared to the untreated GD group $(34.2 \pm 11.5 \mathrm{~cm} / \mathrm{sec})$ at the initial clinical presentation.

Conclusion: We believe that the PSV of the superior thyroidal artery can be used for the differential diagnosis of hyperthyroidism when s cintigraphy is indicated. Thus, the potential dose of radiation received can be lowered and the loss of time can be prevented.

Keywords: Hyperthyroidism; doppler ultrasonography; peak systolic velocity

Received: 26.06.2019; Accepted: 07.07.2020

${ }^{1}$ Recep Tayyip Erdoğan University, Faculty of Medicine, Department of Radiology, Rize, Turkey.

${ }^{2}$ Recep Tayyip Erdoğan University, Faculty of Medicine, Department of Otorhinolariyngology, Rize, Turkey.

${ }^{3}$ Recep Tayyip Erdoğan University, Faculty of Medicine, Department of Internal Medicine, Rize, Turkey.

Corresponding Author: Dr. Tugba Eldes, Recep Tayyip Erdoğan University, Faculty of Medicine, Department of Radiology, Rize, Turkey. e-mail : eldestugba@ gmail.com

This original research was presented in 38. National Radiology Congress, 31 October-04 November 2017, Antalya, Turkey.

How to cite: Eldes T, Turan A, Celiker Beyazal F, et al. Do superior thyroidal artery doppler findings play a aole in the differential diagnosis of hyperthyroidism? Ahi Evran Med J. 2020;4(2):47-52. 


\section{INTRODUCTION}

Hyperthyroidism is a form of thyrotoxicosis that stems from inappropriate production of thyroid hormones by the thyroid gland ${ }^{1}$. The most common causes include Graves' disease (GD) and noduler toxic disease. Early diagnosis and correct treatment of hyperthyroidism are important to prevent systemic complications. Clinical presentation of untreated or partially treated patients with hyperthyroidism might change rapidly, resulting in weight loss, tremor, osteoporosis, atrial fibrillation, embolic events, neuropsychiatric disorders, cardiovascular arrest, and even death ${ }^{2}$. Serum free triiodothyronin (fT3), free thyroxine (fT4), thyroid stimulating hormone (TSH) and radioactive iodine uptake scintigraphy (RAIU) are used in the diagnosis of hyperthyroidism. RAIU is indicated when there are doubts about diagnosis. However, this method cannot be used during pregnancy or breastfeeding ${ }^{2}$. Besides, radiologic examinations are also necessary. Choosing the right diagnostic imaging modality is important in patients with hyperthyroidism. Although ultrasonography is helpful to visualize thyroid parenchyma, it is not enough for differential diagnosis. Color doppler examination during ultrasonography might help to understand parenchymal blood supply changes. However, none of these tests lead to a definitive diagnosis and they are only used for guidance. Thyroid parenchyma might have a heterogenous nodular appearance in the ultrasonographic examination of GD, whereas in toxic multinodular goiter (TMNG) focal involvement in more than one region or intense diffuse involvement might be seen in RAIU. These findings may make it harder to make a differential diagnosis between GD and $\mathrm{TMNG}^{3}$. In addition, duplex doppler ultrasonography (DDUS) might help to obtain some quantitative data. Furthermore, color doppler examination is a routinely recommended practice for differential diagnosis when RAIU is contraindicated, particularly for pregnant and breastfeeding women ${ }^{4}$.Therefore, quantitative data alternative to RAIU can be obtained with DDUS as it can be performed early and easily. The peak systolic velocity (PSV) is measured from the intrathyroidal and inferior thyroid arteries using duplex Doppler ultrasonography (DDUS) ${ }^{5}$. The PSV values of the inferior thyroid artery (ITA) on DDUS were previously found to be very sensitive and specific in identifying Graves' disease ${ }^{6}$. It is suggested that DDUS examination of ITA has a clinical role in the differential diagnosis of autoimmune thyroid diseases and during medical treatment ${ }^{7}$. It is also known that the PSV value of the superior thyroid artery (STA) offers accurate and reliable results due to its easy reproducibility ${ }^{8}$. However, the ability of the PSV value to differentiate patients with GD from those with TMNG is not yet known. In our study, we aimed to find quantitative values (PSV, EDV, RI) that can be alternatives to RAIU examination and lead to diagnosis along with laboratory findings by evaluating DDUS findings of the superior thyroidal artery (STA) in patients with a clinical presentation of hyperthyroidism.

\section{MATERIALS AND METHODS}

This prospective study included 96 individuals consisting of 75 (78.1\%) women and $21(21.9 \%)$ men. For all patients, serum fT3, fT4, TSH, anti-thyroid peroxidase (anti-TPO) antibody, antithyroglobulin (anti-TG) antibody, and thyrotropin receptor antibody (TRAb) levels were tested. The laboratory results were obtained from the data processing system of our hospital. All the patients underwent a routine ultrasound examination.

Participants were divided into three groups: GD group $(n=29)$, TMNG ( $n=41)$, and a healthy euthyroid individuals with normal thyroid parenchyma $(n=26)$. Patients with hyperthyroidism included untreated and treated GD patients, and untreated TMNG patients. GD in an euthyroid-hypothyroid period, euthyroid MNG, patients under 18, and pregnant women were excluded from the study. Among the radiologic examinations, grey scale ultrasonography (US) was performed primarily. During a routine US examination, TMNG and GD patients with heterogenous parenchyma and nodular appearance with indistinct boundaries were evaluated. Parenchymal blood supply properties were checked by color flow doppler ultrasonography. The images showing the 'thyroid inferno' monitored in $\mathrm{GD}^{9}$ and the intranodular vascularity increase monitored in TMNGs ${ }^{10}$ were reviewed. Patients who failed to get a diagnosis with thyroid heterogenous parenchyma and nodular appearance with indistinct boundaries were selected during grey scale and flow Doppler US examinations. For these patients, DDUS of the STA, proximal segments that follow the trace and extend to the thyroid parenchyma, was performed during the US in order to measure PSV, EDV and RI values of the STA for this study. These values were compared with PSV, EDV and RI values of the STA in euthyroid healthy individuals. Ultrasonography and doppler examinations were performed by one specialist in a single-blind manner using 6-15 MHz linear transducer in GE LOGIQ ${ }^{\circledR}$ E9 Color Doppler (GE Company, 2013) imaging system. STA was preferred because it is the first branch of external carotid artery (ECA) and is easily accessible. STA originates from ECA and reaches the thyroid gland right below the greater cornu level of the hyoid bone. We placed a sample volume cursor on the proximal segments that follow the STA trace and extend to the thyroid parenchyma (Figure 1). 


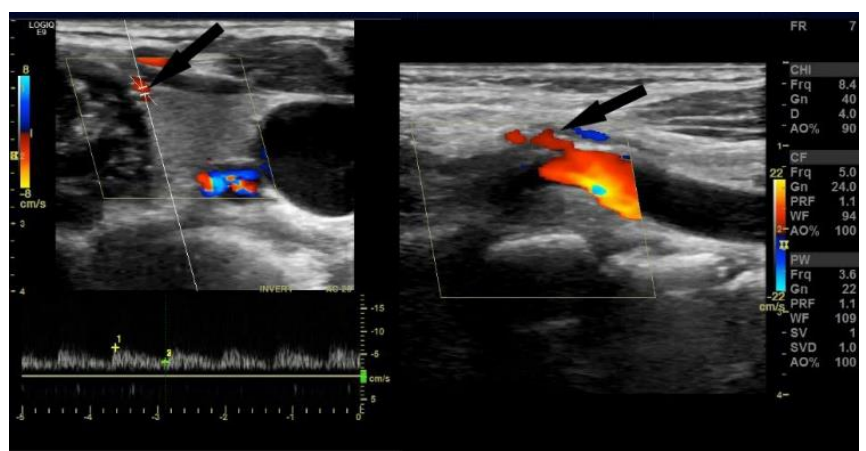

Figure 1: STA trace, proximal segment that extends to the thyroid gland (arrows); STA is the first branch of ECA and reaches the thyroid gland

The angle $(\alpha)$ between the ultrasonography beam and the vessel is selected on the screen with the angle cursor, and the flow velocity envelope curve is displayed on the monitor. Spectral doppler analysis can be calculated for any selected portion of this curve. The angle of insonation was kept between 25-60 degrees. DDUS parameters were frequency $(\mathrm{F}) 6.3 \mathrm{MHz}$, gain $(\mathrm{Gn}) 64 \%$, pulserepetition frequency (PRF) $3.3 \mathrm{KHz}$ and wall-filter (WF) $94 \mathrm{~Hz}$. Measurements were repeated from both sides for three different waveforms, and the average values were recorded. The data of all patients were recorded using a pre-assigned code number (L), and stored digitally. During routine US examination, TMNG and GD patients with heterogenous parenchyma and nodular appearance with indistinct boundaries were evaluated with DDUS. PSV, EDV and RI values were measured and compared with DDUS values of the STA in euthyroid healthy individuals. A statistical analysis was conducted. For quantitative variables, the normality assumption was investigated using Shapiro-Wilk Test. Parametric tests (one-way analysis of variance) were used for variables that have a normal distribution whereas non-parametric tests (Kruskal-Wallis test) were used for variables that do not have a normal distribution. Tukey posthoc test was used after one-way analysis of variance, whereas DunnBonferroni post-hoc test was used after Kruskal Wallis test. Pearson chi-square test was used to investigate the relationship between qualitative variables. Descriptive statistics for quantitative variables that have a normal distribution were given as mean \pm standard deviation, and as mean (25th percentile-75th percentile) for those that do not have a normal distribution. Descriptive statistics for qualitative variables were given in numbers and percentage. Level of significance was determined as 0.05 in all statistical analyses. This study, for which written informed consent was received from all patients, was approved by the Ethics Committee of the Faculty of Medicine, Recep Tayyip Erdogan University. (Approval date: 09/12/2016, Approval Number: 2016/28)

\section{RESULTS}

The study includes 96 individuals consisting of 75 (78.1\%) women and $21(21.9 \%)$ men. The mean age of women was $46.86 \pm 18.63$, and mean age of men was $48.30 \pm 14.84$. There was no statistically significant difference between genders in terms of mean age. Serum hormone values and the clinical characteristics of all patients are provided in Table 1. TRAb values $>1.5 \mathrm{U} / \mathrm{L}$ were considered positive. All these data, radiological reports, and the clinical course of the cases were evaluated by experts. Furthermore, during this process, diagnoses were made.

Table 1. Patients' characteristics and results of serum tests

\begin{tabular}{|c|c|c|c|}
\hline Variable & Control $(n=26)$ & GD $(n=41)$ & TMNG $(n=29)$ \\
\hline Female/male & $22: 04$ & $30: 11: 00$ & 23:06 \\
\hline Age (year) & $25(21-33)$ & $41(35-50)$ & $\begin{array}{l}59.5(53- \\
69.25)\end{array}$ \\
\hline TSH $(\mu \mathrm{IU} / \mathrm{mL})$ & $1.90(1.42-2.41)$ & $\begin{array}{c}0.0002(0.00001- \\
0.0003)^{*} \\
5.32(3.67-\end{array}$ & $\begin{array}{l}0.04(0.00- \\
0.21)^{*}\end{array}$ \\
\hline sT3 (pmmol/L) & $2.99(2.82-3.44)$ & $11.06)^{*}$ & $\begin{array}{c}3.4(3.10-4.09) \\
1.20(1.10-\end{array}$ \\
\hline sT4 (pmmol/L) & $1.00(0.93-1.07)$ & $\begin{array}{c}1.60(1.39-2.60)^{*} \\
145.93(0.44-\end{array}$ & $\begin{array}{c}1.42)^{*} \\
0.35(0.12-\end{array}$ \\
\hline anti TPO (IU/L) & $0.25(0.07-0.36)$ & 763.95)* & 0.47) \\
\hline anti TG (IU/L) & $0.99(0.67-2.28)$ & $\begin{array}{c}40.91(2.33- \\
211.84)^{*}\end{array}$ & $\begin{array}{c}1.05(0.75- \\
1.98)\end{array}$ \\
\hline TRAb (IU/L) & $<1$ & $>1.5$ & $<1$ \\
\hline
\end{tabular}

TRAb was positive in all patients in the GD group. DDUS of the STA was performed. Groups were compared in terms of PSV, EDV and RI values and statistically significant differences were found between them $(p<0.001)$. Dunn-Bonferroni Post hoc test revealed that for PSV, EDV and RI, TMNG (33.85(23.01-44.70) cm/sec, $14.95(10.95-18.58) \mathrm{cm} / \mathrm{sec}, 0.61 \pm 0.047$, respectively) and GD $38.88(33.14-50.05) \mathrm{cm} / \mathrm{sec}, 15.20(13.00-20.02) \mathrm{cm} / \mathrm{sec}, 0.61 \pm 0.054$, respectively) groups were significantly higher values than the control group 21.00(17.51 - 23.85) $\mathrm{cm} / \mathrm{sec}, 10.68(8.24-12.13)$ $\mathrm{cm} / \mathrm{sec}, 0.49 \pm 0.047$, respectively)(all $\mathrm{p}<0.001$ ). Control group can be distinguished from patients with hyperthyroidism in terms of all three values (PSV, EDV, RI) (Figure 2).

The most suitable cut-off values found with Youden index between patients with hyperthyroidism (TMNG and GD) and control group were $27.65 \mathrm{~cm} / \mathrm{sec}$ for PSV, $12.6 \mathrm{~cm} / \mathrm{sec}$ for EDV and 0.57 for RI. However, the differences between untreated TMNG and GD groups (treated and untreated) in terms of PSV, EDV and RI values were not found statistically significant $(\mathrm{p}=0.717, \mathrm{p}=0.713, \mathrm{p}=0.969)$. 

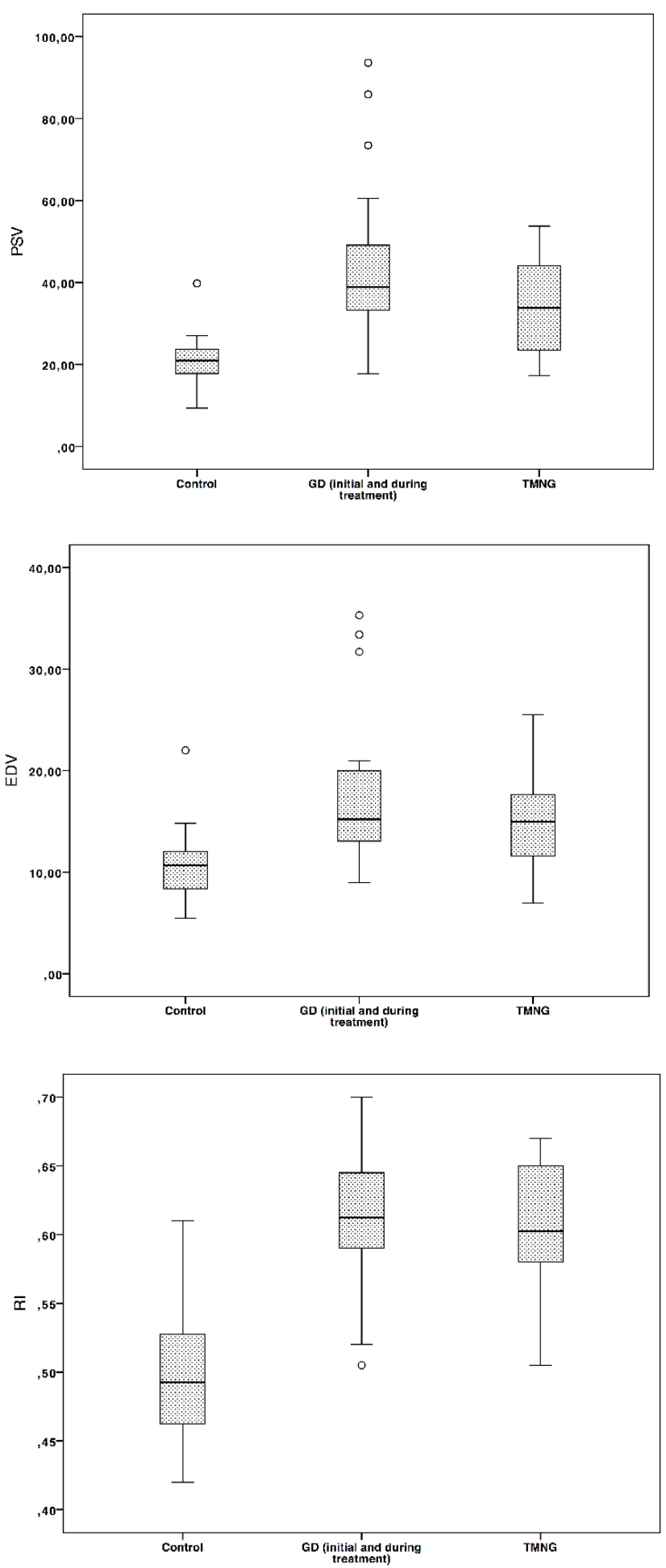

GD: Graves' disease; TMNG: toxic multinodular goiter;RI: resistivity index; PSV: peak systolic velocity; EDV: end-diastolic velocity.

Figure 2. Box plot of PSV, EDV and RI distributions for groups

ROC analysis was performed in order to determine a cut-off point that the parameters (PSV, EDV, RI) might be significant in the study for TMNG and GD groups. The most suitable cut-off point was found to be 0 (zero) in untreated hyperthyroidism groups, according to Youden index. Among the untreated hyperthyroidism patients, only PSV value was found higher and statistically significant in the TMNG group as compared to the GD group (Table 2). Untreated patients (GD and TMNG) among both groups PSV cut-off value is $31.6 \mathrm{~cm} / \mathrm{sec}$ (Table 3 ).

Table 2. Untreated GD and TMNG groups comparison for PSV, EDV and RI

\begin{tabular}{|c|c|c|c|}
\hline & TMNG & GD & p \\
\hline RI & $0.6100 \pm 0.05640$ & $0.6083 \pm 0.04970$ & 0.940 \\
\hline & $50.5222 \pm 26.5666$ & $34.2970 \pm 11.5446$ & \\
\hline PSV & $\begin{array}{l}\mathrm{cm} / \mathrm{sec} \\
14.4000(12.9750-\end{array}$ & $\begin{array}{l}\mathrm{cm} / \mathrm{sec} \\
14.9500(11.6000-\end{array}$ & 0.049 \\
\hline EDV & $32.5500) \mathrm{cm} / \mathrm{sec}$ & $17.6500) \mathrm{cm} / \mathrm{sec}$ & 0.411 \\
\hline
\end{tabular}

Table 3. PSV's cut-off value of compared untreated GD and TMNG groups

\begin{tabular}{ll}
\hline Sensitivity & 0.864 \\
\hline Specificity & 0.95 \\
\hline Positive Predictive Value & 0.95 \\
\hline Negative Predictive Value & 0.864 \\
\hline
\end{tabular}

\section{DISCUSSION}

Hyperthyroidism is a presentation that occurs during the destruction of thyroiditis, TMNG, TA and GD. TMNG development involves the existing nodules gaining autonomous hormone synthesis property ${ }^{11}$. GD is an autoimmune disorder in which TRAb values stimulate the thyroid stimulating hormone (TSH) receptor and increase the production and release of thyroid hormone. In case of toxic adenomas (TA)s, autonomous hormone production might stem from the somatic activating mutations of the genes that regulate thyroid growth and hormone synthesis ${ }^{12}$. Serum hormone values, thyroid parenchyma US, color doppler sonography and RAIU examinations are used for diagnosis. In GD, the sonographic view varies depending on the stage of the disease and other comorbidities, such as nodular goiter and chronic autoimmune thyroiditis ${ }^{13}$. Two different histological patterns were observed in color flow doppler. The first one was the 'thyroid inferno' pattern, consisting of interlobular septa, which includes homogenous cellular parenchymal structures and good capillary vascularization. The second pattern was characterized by peripheral thickened interlobular septa and intraseptal vascularization limiting colloid content within, and includes less cellular structures ${ }^{14}$. Nodules with different echoes exist in patients with TMNG. These nodules are rich in of peri and intranodular vascularization ${ }^{15}$. The treatment includes anti-thyroid drug (ATD), radioiodine treatment and total thyroidectomy. While 
thyroidectomy is a suitable treatment for some forms of hyperthyroidism, ATDs are beneficial in just some of the cases ${ }^{2}$. Therefore, it is important to make an early diagnosis. Apart from serum hormone levels, RAIU examination takes time and involves radiation exposure. As a result of RAIU examination, more than one region exhibits focal increase in TMNG parenchyma and if these areas expand, it might be hard to distinguish the appearance from $\mathrm{GD}^{16}$. Color doppler US, on the other hand, reveals increased flow in the parenchyma due to thyroid hyperactivity and it can only help distinguishing from destructive thyroiditis (DT) ${ }^{8}$. In this study, we also concluded that in addition to laboratory findings, DDUS examination of STA might bring an extra contribution to the differential diagnosis of hyperthyroidism. DDUS has advantages over RAIU as it allows saving time and does not involve radiation exposure. In a study, it was found that thyroid parenchymal blood supply and PSV of the STA was helpful in the differential diagnosis of untreated GD and destructive thyroiditis cases. It was detected that the GD STA-PSV values were significantly higher than the DT values. Accordingly, the cut off value was $43 \mathrm{~cm} / \mathrm{sec}^{17}$. In a similar study on the differential diagnosis of hyperthyroidism, STA-PSV values in untreated GD were significantly higher compared to those in DT cases. The STA-PSV cut off value was $41.3 \mathrm{~cm} / \mathrm{sec}^{18}$. Again, in a study that compares RAIU levels and PSV values of STA in DDUS for GD and DT patients, significant results were reported for PSV (average optimum cut off value was $42.25 \mathrm{~cm} / \mathrm{sec}$ ) ${ }^{19}$. It was mentioned that the blood flow parameters obtained in DDUS examination of the superior thyroidal artery can be used in the clinical diagnosis of patients with hyperthyroidism ${ }^{20,21}$. It was mentioned that PSV values of STA might be complementary to RAIU in order to distinguish the causes of hyperthyroidism ${ }^{22}$. These studies imply that especially PSV values of STA can be used in differential diagnosis of patients with hyperthyroidism. In some studies with similar outcomes, PSV measurements were conducted from the inferior thyroidal artery (ITA). ITA was preferred because it constitutes a large part of the thyroid blood flow. The measurements were performed from parenchymal segments parallel to the common carotid artery of ITA ${ }^{23,24}$. We chose STA because it was easily accessible and easy to designate. In the literature, unlike GD, the number of the studies on the STA- PSV of TMNG are limited. Boi et al. ${ }^{3}$ measured PSV values from the intraparenchymal vascular structures in GD cases, and from the intranodular vascular structures in TMNG cases. They found that GD-PSV value was $58.6 \pm 3.1 \mathrm{~cm} / \mathrm{sec}$, and TMNG-PSV value was $46 \pm 16 \mathrm{~cm} / \mathrm{sec}$. In our study, PSV values received from STA's of the cases with TMNG were similar to those reported in other studies $(50.5 \pm 26.5 \mathrm{~cm} / \mathrm{sec})$.
We believe that these high PSV values are based on perinoduler and intranodular hypervascularization in TMNG. No statistically significant difference was detected when the PSV values of the TMNG group were compared to those of all the GD cases in which increased parenchymal vascularity was observed. However, the STA-PSV values of our untreated GD group $(34.2 \pm 11.5 \mathrm{~cm} / \mathrm{sec})$ were significantly lower than those of the TMNG group. This may be due to the change in parenchymal vascularization properties of GD patients during the course of the disease. Our data are also compatible with the previous series, indicating that DDUS examination can be used for the differential diagnosis of hyperthyroidism.

Hashimoto's thyroiditis cases were not included in our study since duplex doppler ultrasonography (DDUS) applications depend on the users.

We believe that, along with laboratory findings, the PSV value of STA might be an alternative to RAIU examination in the differential diagnosis of hyperthyroidism and that it can support the diagnosis. Thus, the potential dose of radiation to be received can be lowered and the loss of time can be prevented.

\section{CONFLICT OF INTEREST}

The authors declare no conflict of interest.

\section{ACKNOWLEDGMENTS}

We thank Serap Baydur Sahin for sending her patients.

\section{REFERENCES}

1. Hari Kumar KS, Pasupuleti V, Jayaraman M, et al. Role of thyroid Doppler in differential diagnosis of thyrotoxicosis. Endocr Prac. 2009;15(1):6-9.

2. Ross DS, Burch HB, Cooper DS, et al. 2016 American Thyroid Association Guidelines for Diagnosis and Management of Hyperthyroidism and Other Causes of Thyrotoxicosis. Thyroid. 2016;26(10):1343-1421.

3. Boi F, Loy M, Piga M, et al. The usefulness of conventional and echo colour Doppler sonography in the differential diagnosis of toxic multinodular goitres. Eur J Endocrinol. 2000;143(3):339-346.

4. Turkish Society of Endocrinology and Metabolism. Guideline for diagnosis and treatment of thyroid diseases 2017. http://temd.org.tr/admin/uploads/tbl_kilavuz/20180518105146-2018-0518tbl_kilavuz105136.pdf . 2017:84-85. Accessed on 19/05/2018.

5. Erdogan MF, Anil C, Cesur M, et al. Color flow Doppler sonography for the etiologic diagnosis of hyperthyroidism. Thyroid.2007;17(3):223-228.

6. Hari Kumar KV, Vamsikrishna P, Verma A, et al. Evaluation of thyrotoxicosis during pregnancy with color flow Doppler sonography. Int J Gynaecol Obstet. 2008;102(2):152-155. 
7. Caruso G, Attard M, Caronia A, et al. Color Doppler measurement of blood flow in the inferior thyroid artery in patients with autoimmune thyroid diseases. Eur J Radiol. 2000;36(1):5-10.

8. Bogazzi F, Vitti P. Could improved ultrasound and power Doppler replace thyroidal radioiodine uptake to assess thyroid disease? Nat Clin Pract Endocrinol Metab. 2008;4(2):70-71

9. Vitti P, Rago T, Mazzeo S, et al. Thyroid blood flow evaluation by colorflow Doppler sonography distinguishes Graves' disease from Hashimoto's thyroiditis. J Endocrinol Invest.1995;18(11):857-861.

10. Becker D, Bair HJ, Becker W, et al. Thyroid autonomy with color-coded image-directed Doppler sonography: internal hypervaskularization for the recognition of autonomous adenomas. J Clin Ultrasound. 1997;25(2):63-69.

11. Berghout A, Wiersinga WM, Smits NJ, et al. Interrelationships between age, thyroid volume, thyroid nodularity, and thyroid function in patients with sporadic nontoxic goiter. Am J Med. 1990;89(5):602-608.

12. Gozu HI, Lublinghoff J, Bircan R, et al. Genetics and phenomics of inherited and sporadic non-autoimmune hyperthyroidism. Mol Cell Endocrinol. 2010;322(1-2):125-134.

13. Mazzaferri EL. Thyroid cancer and Graves' disease. J Clin Endocrinol Metab.1990;70(4):826-829.

14. Kawai K, Tamai H, Mori T, et al. Thyroid histology of hyperthyroid Graves'disease with undetectable thyrotropin receptors antibodies. J Clin Endocrinol Metab.1993;77(3):716-719.

15. Clark KJ, Cronan JJ, Scola FH. Color Doppler sonography: anatomic and physiologic assesment of the thyroid. J Clin Ultrasound. 1995;23(4):215-223.

16. Summaria V, Salvatori M, Rufini V, et al. Diagnostic imaging in thyrotoxicosis. Rays.1999;24(2):273-300.

17. Hiraiwa T, Tsujimoto $\mathrm{N}$, Tanimoto $\mathrm{K}$, et al. Use of Color Doppler Ultrasonography to Measure Thyroid Blood Flow and Differentiate Graves' Disease from Painless Thyroiditis. Eur Thyroid J. 2013;2(2):120-126.

18. Kim TK, Lee EJ. The value of the mean peak systolic velocity of the superior thyroidal artery in the differential diagnosis of thyrotoxicosis. Ultrasonography. 2015;34(4):292-296.

19. Chen L, Zhao X, Liu H, et al. Mean peak systolic velocity of the superior thyroid artery is correlated with radioactive iodine uptake in untreated thyrotoxicosis. J Int Med Res. 2012;40(2):640-647.

20. Karakas O, Karakas E, Cullu N, et al. An evaluation of thyrotoxic autoimmune thyroiditis patients with triplex Doppler ultrasonography. Clin Imaging. 2014;38(1):1-5

21. Uchida T, Takeno K, Goto M, et al. Superior thyroid artery mean peak systolic velocity for the diagnosis of thyrotoxicosis in Japanese patients. Endocr J. 2010;57(5):439-443.

22. Zhao X, Chen L, Li L, et al. Peak Systolic Velocity of Superior Thyroid Artery for the Differential Diagnosis of Thyrotoxicosis. PLoS One. 2012;7(11):7-12.

23. Banaka I, Thomas D, Kaltsas G. Value of the left inferior thyroid artery peak systolic velocity in diagnosing autoimmune thyroid disease. J Ultrasound Med. 2013;32(11):1969-1978.

24.Donkol RH, Nada AM, Boughattas S. Role of color doppler in differentiation of Graves' disease and thyroiditis in thyrotoxicosis. World $\mathbf{J}$ Radiol. 2013;5(4):178-183. 